\title{
A meta-analysis contrasting active versus passive restoration practices in dryland agricultural ecosystems
}

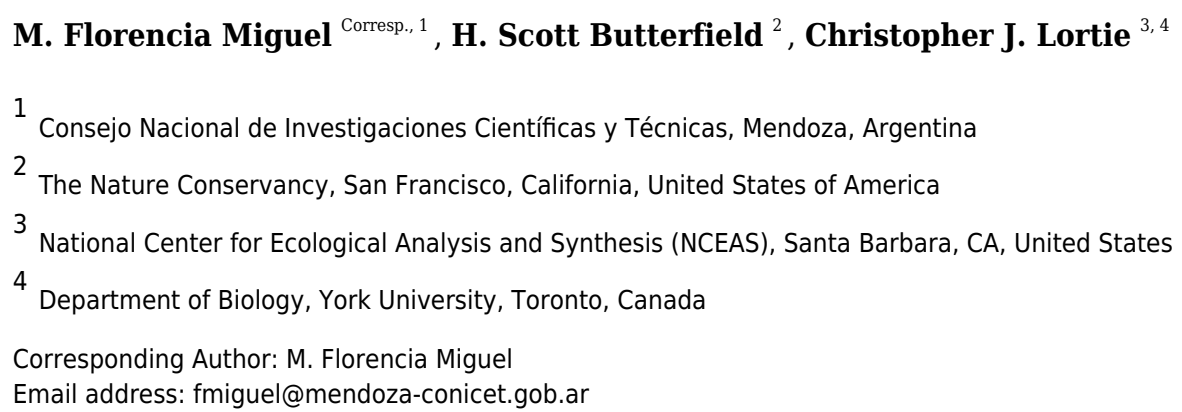

Restoration of agricultural drylands globally, here farmlands and grazing lands, is a priority for ecosystem function and biodiversity preservation. Natural areas in drylands are recognized as biodiversity hotspots and face continued human impacts. Global water shortages are driving increased agricultural land retirement providing the opportunity to reclaim some of these lands for natural habitat. We used meta-analysis to contrast different classes of dryland restoration practices. All interventions were categorized as active and passive for the analyses of efficacy in dryland agricultural ecosystems. We evaluated the impact of 19 specific restoration practices from 42 studies on soil, plant, animal, and general habitat targets across 16 countries, for a total of 1,427 independent observations. Passive vegetation restoration and grazing exclusion led to net positive restoration outcomes. Passive restoration practices were more variable and less effective than active restoration practices. Furthermore, passive soil restoration led to net negative restoration outcomes. Active restoration practices consistently led to positive outcomes for soil, plant, and habitat targets. Water supplementation was the most effective restoration practice. These findings suggest that active interventions are necessary and critical in most instances for dryland agricultural ecosystems likely because of severe anthropogenic pressures and concurrent environmental stressors - both past and present. 
1 A meta-analysis contrasting active versus passive restoration practices in dryland agricultural

2

3

4

5 M. Florencia Miguel ${ }^{1}$, H. Scott Butterfield ${ }^{2}$, Christopher J. Lortie ${ }^{3,4}$ ecosystems

6

$8 \quad{ }^{1}$ National Council for Scientific and Technical Research (CONICET), Mendoza, Argentina.

$9 \quad{ }^{2}$ The Nature Conservancy, San Francisco, CA, United States of America.

$10{ }^{3}$ Department of Biology, York University, Toronto, Canada.

$11{ }^{4}$ National Center for Ecological Analysis and Synthesis (NCEAS), Santa Barbara, CA, United

12 States of America.

13

14

15 Corresponding Author

16 M. Florencia Miguel ${ }^{1}$

17 Av. Ruiz Leal s/n Parque General San Martín, Mendoza, 5500, Argentina.

18 E-mail: fmiguel@mendoza-conicet.gob.ar

19

20

21 


\section{Abstract}

24 Restoration of agricultural drylands globally, here farmlands and grazing lands, is a priority for

25 ecosystem function and biodiversity preservation. Natural areas in drylands are recognized as

26 biodiversity hotspots and face continued human impacts. Global water shortages are driving

27 increased agricultural land retirement providing the opportunity to reclaim some of these lands

28 for natural habitat. We used meta-analysis to contrast different classes of dryland restoration

29 practices. All interventions were categorized as active and passive for the analyses of efficacy in

30 dryland agricultural ecosystems. We evaluated the impact of 19 specific restoration practices

31 from 42 studies on soil, plant, animal, and general habitat targets across 16 countries, for a total

32 of 1,427 independent observations. Passive vegetation restoration and grazing exclusion led to

33 net positive restoration outcomes. Passive restoration practices were more variable and less

34 effective than active restoration practices. Furthermore, passive soil restoration led to net

35 negative restoration outcomes. Active restoration practices consistently led to positive outcomes

36 for soil, plant, and habitat targets. Water supplementation was the most effective restoration

37 practice. These findings suggest that active interventions are necessary and critical in most

38 instances for dryland agricultural ecosystems likely because of severe anthropogenic pressures

39 and concurrent environmental stressors - both past and present. 


\section{Introduction}

44 Dryland ecosystems are a dominant land cover type globally (White \& Nackoney, 2003),

45 encompassing many natural habitats such as grasslands, shrublands, and deserts (Reid et al.,

46 2005). Human-influenced agricultural ecosystems such as farmlands and grazing lands are also

47 common in drylands globally (Ramankutty et al., 2008; Kennedy et al., 2019). Natural habitats

48 within dryland ecosystems are hotspots of biodiversity and provide important ecosystem services

49 including food provision, water regulation, and carbon sequestration (Millennium Ecosystems

50 Assessment (MEA), 2005; Castro et al., 2018; Díaz et al., 2018). These services support nearly

$5140 \%$ of the world's population (Castro, Quintas-Soriano \& Egoh, 2018). However, land

52 conversion, land degradation and climate change (Reynolds et al., 2007; Webb et al., 2017) have

53 greatly impacted these ecosystems (Millennium Ecosystems Assessment (MEA), 2005) leading

54 to some of the highest concentrations of threatened and endangered species worldwide

55 (Bonkoungou, 2001). Drylands are thus an important set of ecosystems to manage from both

56 anthropogenic and ecological perspectives, and synthesis of existing research will inform

57 knowledge for balancing restoration with opportunity and change.

Dryland ecosystem degradation has led to an increase in restoration actions recognizing the

59 high vulnerability of these systems to human impacts (Reynolds et al., 2007; James et al., 2013)

60 and the multiple restorative benefits both to natural systems and human populations (Clewell \&

61 Aronson, 2006; De Groot et al., 2013; Castro et al., 2018). Ecological restoration includes many

62 different types of practices oriented to the recovery of degraded ecosystems and focuses on

63 diverse targets such as plants, animals, soils, habitats, and ecosystem functions (Clewell \&

64 Aronson, 2006; Perino et al., 2019). Based on the amount of resources and human effort

65 invested, restoration practices can be classified as active (i.e. requiring human input) or passive 
66 (i.e. requiring limited to no human input or removal of input such as perturbations) (Hobbs \&

67 Cramer, 2008). The class of restoration practice to implement depends on the type and extent of

68 damage to the ecosystem. For example, the type and extent of damage can vary greatly from

69 farmlands - where natural plant cover and animal species have been completely removed - to

70 grazing lands - which still have a significant presence of both. Generally, more degraded

71 ecosystems will require more active efforts to be restored (Hobbs \& Cramer, 2008). The specific

72 restoration goal and the availability of funding will further define the type of restoration applied

73 locally or regionally (Miller \& Hobbs, 2007; Aronson and Alexander, 2013; Chazdon et al.,

74 2017). Therefore, a synthesis comparing active and passive practices will provide an analysis of

75 trends in global restoration practices, identify outcomes reported from different restoration

76 practices (Gavin, 2010), and will therefore begin to inform future restoration so as to ensure

77 limited resources are applied using evidence and, as efficiently as possible, in a given general

78 context of constraints.

Global agricultural intensification is likely to continue in order to meet the demands of a 80 growing human population (Tilman et al., 2011; World Health Organization, 2018). However,

81 global water scarcity particularly in dryland agricultural ecosystems - farmlands and grazing

82 lands - impacted by overexploitation, land degradation, and climate change is increasingly

83 driving retirement of those agricultural lands that are no longer productive (Benayas et al., 2007;

84 ELD Initiative, 2015). For instance, more than 200,000 acres of irrigated farmlands in California

85 are predicted to be retired in the next 10 to 20 years as part of a strategy for sustainable

86 groundwater use (Kelsey et al., 2018; Hanak et al., 2019; Bryant et al., 2020). This general

87 sociopolitical and ecological context provides the opportunity to re-claim some of these lands for

88 native plants and animals through habitat restoration (Queiroz et al., 2014; Kelsey et al., 2018). 
89 Limitations in lands as set asides for plant and animal species has been proposed as a critical

90 issue in all systems globally (Diamond, 1975; Gotelli \& McCabe, 2002) and evidence-informed

91 decisions for habitat restoration can contribute to the recovery of plant and animal species

92 worldwide. Restoration of agricultural drylands back to habitat for plants and animals will

93 provide capacity for reductions in species loss in these biodiversity hotspots (Durant et al., 2012;

94 Lortie et al., 2018) and contribute to more secure water and food resources for a rapidly

95 expanding human population (Tilman et al., 2011; Kelsey et al., 2018).

96 The main purpose of this global synthesis was to examine the extent of research on specific

97 restoration practices in agricultural dryland ecosystems and to identify any general trends in the

98 success of these practices for restoring native habitat. The following three goals were specifically

99 examined: whether a classification of restoration practices into active and passive is a

100 meaningful simplification of the complexity of restoration research for dryland agricultural

101 ecosystems; the overall effectiveness of active versus passive restoration practices; and the

102 outcomes identified by the restoration practices reported. The outcomes of a synthesis on

103 drylands restoration practices can be used as a mechanism to structure evidence-based

104 discussions and planning by researchers and stakeholders, and to yield insight into the

105 interventionist efforts carried out for agricultural dryland restoration.

107 Survey methodology

108 Literature search and eligibility criteria

109 PRISMA (Preferred Reporting Items for Systematic reviews and Meta-Analyses) guidelines

110 were used to structure this meta-analysis (Fig. 1) (Moher et al., 2009). We systematically

111 searched Scopus and The Web of Science using the following term combinations: [restoration* 
112 desert* vegetation*] OR [restoration* grassland* desert*] OR [restoration desert* plant*] OR

113 [restoration "agricultural lands"] OR ["restoration techniques" desert*] OR ["passive restoration"

114 desert* plant*] OR ["active restoration" desert* plant*] OR [revegetation abandoned desert*] OR

115 [restoration "agricult*land*" desert* plant*] OR [restoration dryland* vegetation] OR

116 [restoration semiarid* plant*] OR [restoration arid* plant*]. The searches were done in

117 September 2018 and then updated in January 2020 and returned 2077 published articles. We

118 collected data from studies that met the following inclusion criteria: (1) research articles that

119 included numerical results; review and theoretical articles were not included; (2) agriculture

120 (farmlands and grazing lands - we grouped these agricultural practices within our analysis even

121 though there may be reasons to conduct synthesis or meta-analysis for these land uses separately,

122 including potentially large differences in the extent of disturbance and type and intensity of

123 restoration required to return the site to a natural state) as the main disturbance reported; (3)

124 studies demonstrating a clear comparison of restoration practices and reference groups (i.e. intact

125 or minimally disturbed condition) (Wortley, Hero \& Howes, 2013); (4) reported statistical

126 analysis and significance of treatments. We categorized all the reported terms that referred to

127 agricultural land uses into a single term entitled "agricultural dryland ecosystems" (Fig. 2 for

128 details on terminology for the land uses included in this meta-analysis). Agricultural land uses

129 prior to the implementation of restoration practices included a variety of crop species and grazing 130 systems globally (Table 1).

131 After the application of PRISMA guidelines and the above inclusion criteria, a total of 42

132 peer-reviewed articles (Fig. 1; Table S1) and 1,427 independent observations, from 16 different

133 countries (Fig. 3; Table 2), were included in the meta-analysis. We defined an independent 
134 observation as a repeated, separate test in a different location listed within the 42 articles

135 (Koricheva, Gurevitch \& Mengersen, 2013).

136

137 Data extraction

138 We extracted the following three primary elements from each article: (1) the specific

139 restoration practice implemented (e.g. natural recovery of vegetation); (2) the restoration goal

140 (hereafter restoration outcome) reported by the study researchers that was explicitly linked to a

141 clearly described restoration practice (e.g. vegetation restoration); and 3) the reported response

142 variables listed for each independent observation (Table 3).

143 Each of the 19 restoration practices was further categorized as active or passive to facilitate

144 factor analysis and partition heterogeneity between studies in a transparent, a priori designation

145 (Ioannidis, Patsopoulos \& Evangelou, 2007; Koricheva \& Gurevitch, 2014). Passive restoration

146 practices included those that focused on natural regeneration with minimal to no human

147 interventions (DellaSala et al., 2003; Hobbs \& Cramer, 2008), such as the cessation of

148 disturbance from cattle or livestock grazing (Filazzola et al., 2020). Active restoration practices

149 included those that involved direct human interventions (Holl \& Aide, 2011), such as

150 remediating soil (e.g. nutrient addition) and adding vegetation back to the system (e.g. planting

151 and seeding).

152 Specific restoration practices were rarely replicated globally. Consequently, we classified

153 passive restoration practices into the following categories based on their primary focus: soil,

154 vegetation, and grazing exclusion. Passive restoration practices focused on soils restoration, such

155 as mycorrhizal recovery, or on vegetation restoration, such as plant facilitation, and were

156 classified within soil and vegetation categories respectively (Table 3). Grazing exclusion was 
157 classified as a passive restoration practice because grazing was removed, and no other

158 interventions were applied. We grouped active restoration practices into the following categories

159 based on their primary focus: soil, vegetation, and water supplementation. Active restoration

160 practices focused on soils restoration, such as mycorrhizal inoculation, or on vegetation

161 restoration, such as seeding, and were classified within soil and vegetation categories,

162 respectively. Water supplementation included practices such as irrigation (Table 3).

163 Restoration outcomes for active and passive practices were grouped into the following

164 categories: soil, vegetation, animals, and habitat. The response variables related to soil measures

165 (e.g. nutrient content) were included within the soil category. The vegetation category included

166 plant measures such as plant cover and abundance. The animal category included measures of

167 invertebrate abundance, diversity, and richness. The studies that met the above inclusion criteria

168 and were related to the restoration of animal populations, were focused exclusively on

169 invertebrates. This could be a limitation when trying to generalize about animal restoration

170 practices and outcomes. For the vegetation and animal studies, we did not record species

171 composition or species provenance. The habitat category included measures of both soil and

172 vegetation restoration reported together, or measures of general community structure, such as

173 plant productivity and species evenness (Table 3).

174 For each reported response variable, we extracted the mean and standard deviation, the

175 number of replicates, and the target taxa for restoration. These quantitative data were extracted

176 for the two groups evaluated at each study including the treatment and reference groups. When

177 these data were provided in figures within an article, we used WebPlotDigitizer (Rohatgi, 2019)

178 to extract values. In addition, we collected mean annual temperature and annual precipitation

179 data from each study site to calculate an aridity index (Martonne, 1927), and then recorded the 
180 reported duration of each study. When climatic data were not provided in the studies, we used

181 the latitude and longitude listed to look up the means from WorldClim (www.worldclim.org).

182 The aridity index and duration of studies were used as covariates in our statistical models. We

183 also reviewed the spatial grain size (i.e. minimum size of units of observation) (Gustafson, 1998)

184 of each study.

185

186 Statistical analysis

187 To estimate the effect of active and passive restoration practices, we calculated the log

188 response ratio (lrr) (Hedges et al., 1999). This index measures the effect size of a treatment over

189 a control group (Lajeunesse, 2015); in this work, lrr represents the effect size of the restoration

190 practice as the log-proportional change between the means of the treatment and reference groups.

191 Thus, a positive $l r r$ value indicates the effect of the restoration practice was higher than that of

192 the reference group (i.e. the restoration practice has a positive impact on restoration outcomes)

193 while a negative $l r r$ value indicates the effect of the reference or control group was higher than

194 that of the restoration practice. A lrr value of zero represents no net effect of the restoration

195 practice on restoration outcomes (Pustejovsky, 2018).

196 We used random effects models to account for the variability between studies (e.g.

197 different restoration practices implemented, response outcomes pursued, and response variables

198 measured) (Schwarzer, Carpenter \& Rücker, 2015). Post hoc meta-regressions were then used to

199 test the influence of aridity (Martonne, 1927) and time from onset of study. Statistical

200 significance of active and passive restoration practices was tested with t-tests against a value of

201 0. Restoration practices and outcomes were considered significant if their estimated 95\%

202 confidence intervals did not overlap 0 (Cote \& Jennions, 2013). All analyses were done in R 
203 version 3.4.4 (R Core Team, 2018). The meta and metaphor packages were used for the meta-

204 analysis (Schwarzer, 2007; Viechtbauer, 2010).

\section{Results}

207 This meta-analysis included 42 peer-reviewed articles covering 16 countries in dryland agricultural ecosystems (Fig. 3; Table 2). The meta-analysis included the evaluation of 19

209 different restoration practices, categorized into three active and three passive practices, on restoration outcomes (Table 3). There were a total 1,427 independent observations (or data

211 entries) from the 42 articles that were analyzed in the meta-analysis (Miguel, Butterfield \&

212 Lortie, 2020). The mean spatial grain size for the studies was $2,320.1 \mathrm{~m}^{2}$ for active and 814.15

$213 \mathrm{~m}^{2}$ for passive restoration practices (Table $\mathrm{S} 2$ ).

214 Active restoration practices consistently led to positive restoration outcomes (Table 4).

215 All three categories of active restoration, including soil, vegetation, and water supplementation,

216 had net positive responses. Water supplementation was the most effective restoration practice,

217 followed by soil and vegetation restoration practices (Table 4A, Fig. 4). When analyzing

218 restoration outcomes, we found that soils, vegetation, and habitat are likely to be restored

219 through active restoration practices, but that invertebrate animal communities were not (Table 220 4B).

221 Passive restoration practices had lower and more variable effect sizes when compared to 222 active restoration practices (Table 4A). Passive restoration of vegetation and grazing exclusion

223 had positive effects on restoration outcomes (Table 4A, Fig. 4). However, passive soil restoration 224 practices led to negative restoration outcomes (Table 4A, Fig. 4). Soils did not passively recover 
225 in agricultural drylands, but plants and habitat did passively recover in some instances (Table 226 4B).

227 Aridity had a weak negative impact on active restoration practices suggesting that water

228 limitations can mediate the positive results of these practices on restoration outcomes (lrr aridity $229=-0.02,95 \% \mathrm{CI}=-0.03$ to -0.02$)$. For active restoration practices, increasing the duration of the 230 study had a significant, but small positive impact on restoration $(l r r$ time $=0.003,95 \% \mathrm{CI}=$ 2310.002 to 0.0034 ), suggesting longer studies be considered when evaluating the impact of active 232 restoration practices on restoration outcomes. For passive restoration practices, the duration of 233 the study negatively influenced restoration outcomes, but variation in aridity had no effect (lrr 234 time $=-0.003,95 \% \mathrm{CI}=-0.003$ to $-0.002 ; \mathrm{lr} r$ aridity $=-0.003,95 \% \mathrm{CI}=-0.006$ to 0.005 ).

\section{Discussion}

237

238

239

240

241

242

243

244

\section{The need for a meta-analysis of restoration practices in dryland agricultural ecosystems}

Active versus passive restoration strategies is a critical decision in the management of agricultural drylands globally, and the aggregated evidence confirmed that there are consistent and crucial differences between this simple grouping of practices. The opportunity to restore agricultural systems is increasing globally particularly in farmlands in dryland ecosystems that are experiencing intensifying water shortages and resulting land retirement (Benayas et al., 2007; Kelsey et al., 2018). Unfortunately, ecological restoration is neither a simple concept nor "one size fits all" group of practices with known outcomes (Higgs, 1997). Instead, there are numerous potential combinations of restoration practices across most systems, including in drylands, which are infrequently replicated globally. The low replicability of individual restoration practices is a potential limitation for using the results of this synthesis to inform global decision making for 
248 restoration. However, synthesis of practices helps to simplify and aggregate the global evidence

249 to explore generality and to advance theory in this field.

250 Ecological restoration is a broad set of interventions that comprise practices conducted in a

251 wide range of ecosystems globally (Hobbs \& Cramer, 2008). In tropical and temperate rain

252 forests, previous meta-analyses have shown that passive restoration including natural succession

253 processes can lead to positive, desired plant and animal restoration outcomes (Crouzeilles et al.,

254 2017; Meli et al., 2017). Nevertheless, for drylands, this meta-analysis showed that active

255 restoration practices more consistently led to positive restoration outcomes. The likelihood of

256 efficacy between active and passive restoration practices can be explained by the physical

257 constraints of these ecosystems that experience relatively severe limitations in rainfall, soil

258 fertility, and productivity (Millennium Ecosystems Assessment (MEA), 2005). To this end,

259 aridity was a significantly limiting factor in the models for active restoration outcomes

260 suggesting that drylands pose unique challenges and considerations for effective application of

261 interventions. Moreover, the extent of land transformation and the type of prior land use can also

262 contribute to the requirement of increased efforts and investments (Holl \& Aide, 2011) to

263 achieve agricultural dryland restoration. Collectively, this evidence supports previous research

264 and highlights the need for consideration of environmental limitations in drylands.

\section{The outcome of active versus passive restoration practices}

Importantly, active restoration practices are required to achieve soil-based outcomes in farmlands in agricultural drylands, while passive practices lead to negative soil restoration outcomes. Because soils constitute the foundation for long-term ecosystem recovery (Costantini et al., 2016), it is likely that any successful effort would require some form of active restoration. 
271 For instance, mycorrhizal inoculation contributes to the restoration of soil microorganisms and

272 the subsequent successful establishment and growth of the desired shrub species (e.g. Caravaca

273 et al., 2003); and carbon addition increases the availability of soil nutrients for plants and moss

274 cover in former agricultural drylands (e.g. Török et al., 2014). This result is consistent with

275 previous work from the San Joaquin Desert of California that recommends any restoration

276 project on formerly farmed lands start with soil nutrient remediation (Laymon et al., 2010).

277 Despite the fact that we did not separately evaluate restoration outcomes for farmlands and

278 grazing lands in this study, soil restoration efforts are much more likely to be required in

279 farmlands (versus grazing lands) because of the extent of the damage - including from tilling and

280 synthetic inputs to increase crop productivity - in these intensively managed systems (Garibaldi

281 et al., 2019; Kleijn et al., 2019). Although resources can be limiting for restoration, particularly

282 for large-scale projects that will have the most significant impacts on ecosystem services and

283 biodiversity, active restoration may be necessary in order to overcome the legacies of soil

284 disturbances, nutrient additions, and pesticide usage (Kleijn et al., 2019) in agricultural drylands.

285 Once soil restoration is achieved, plant restoration can proceed, actively or passively. The

286 passive restoration of plant species is an emerging strategy for restoring native communities with

287 minimal costs (Hobbs \& Cramer, 2008; Tabeni et al., 2017). Moreover, the removal of grazing

288 was an effective strategy for passive restoration in drylands, similar to the findings from a recent

289 global grazing meta-analysis (Filazzola et al., 2020). Nevertheless, in some more mesic grazing

290 systems, like in the coastal and northern interior portions of California, removing grazing can

291 lead to greater dominance of non-native plant species and overall lower levels of native plant and

292 animal biodiversity (Hayes \& Holl, 2003; Marty, 2005). Active plant restoration such as seeding

293 and planting also led to positive outcomes and likely requires water supplementation. However, 
294 as the species origin of the restored plant communities was not evaluated in this meta-analysis,

295 the decision for active or passive plant restoration practices will depend on the biotic context of

296 the site and the species-specific restoration goals of the project. Future studies can examine this

297 limitation by specifically assessing species diversity of restored agricultural drylands under 298 different restoration practices.

299 Although some passive restoration practices led to positive restoration outcomes, these

300 results were more variable and at lower levels than the ones found by active restoration practices.

301 The aridity of sites and the duration of treatments had contrasting influence on the restoration

302 outcomes of different practices reflecting the dependence on context for the outcomes of

303 restoration projects (Gravuer et al., 2018) and the influence of physical constraints to the success

304 of restoration practices (Miller \& Hobbs, 2007). However, a focus on intensively (farmlands) and

305 extensively (grazing lands) managed agricultural drylands and their restoration outcomes

306 contributes to a more general understanding of the restoration practices because of the relatively

307 high variety of intervention tested. Finally, data on animal restoration outcomes was limited to

308 invertebrate community-based studies, a taxa that is known to be severely impacted by

309 agricultural practices (Potts et al., 2010; Garibaldi et al., 2011; Sánchez-Bayo and Wyckhuys,

310 2019). This research gap highlights the difficulties in restoring animal community targets even if

311 soil and plant restoration is successful at a specific site. More comprehensive studies of

312 restoration outcomes and extended biodiversity analyses in agricultural drylands are necessary to

313 better assess the extent of intervention needed.

314

315 Conclusions 
317 to inform evidence-based decision making for stakeholders (Gavin, 2010). Considering the

318 opportunity to restore agricultural dryland ecosystems globally, meta-analysis can reveal broad

319 trends in data that inform decision-making about the restoration practices most likely to achieve

320 certain restoration outcomes. This meta-analysis revealed that you can get some restoration

321 outcomes for "free" but, as we noted, these outcomes may be more variable in these systems.

322 Nevertheless, with limited resources, active restoration practices are required to achieve positive

323 restoration outcomes, likely because of severe anthropogenic pressures and concurrent

324 environmental stressors - both past and present - in dryland agricultural ecosystems. Facing the

325 opportunity of reclaiming drylands formerly used for agricultural practices, soils will require

326 active restoration interventions; and when resources for restoration do exist, we may focus

327 efforts on native plant species restoration and potentially more specifically those that serve a

328 foundational or keystone role (e.g. shrubs) (Lortie et al., 2016) within the ecosystem.

\section{Acknowledgments}

332 We acknowledge The Nature Conservancy and York University for their support to this

333 synthesis. C.J.L. is thankful for a Senior Research Fellow at NCEAS. M.F.M. thanks CONICET

334 for a postdoctoral fellowship at the Argentine Dryland Research Institute. 


\section{References}

352

353 Aronson J, Alexander S. 2013. Ecosystem restoration is now a global priority: Time to roll up 354 our sleeves. Restoration Ecology 21:293-296. DOI: 10.1111/rec.12011.

355 Benayas JMR, Martins A, Nicolau JM, Schulz JJ. 2007. Abandonment of agricultural land: An 356 overview of drivers and consequences. CAB Reviews: Perspectives in Agriculture, 357 Veterinary Science, Nutrition and Natural Resources 2. DOI: 10.1079/PAVSNNR20072057.

359 Bonkoungou EG. 2001. Biodiversity in drylands: challenges and opportunities for conservation $360 \quad$ and sustainable use. :1-20.

361 Bryant BP, Kelsey TR, Vogl AL, Wolny SA, Selmants P, Biswas, Tanushree Butterfield HS. 
362 2020. Shaping land use change and ecosystem restoration in a water stressed agricultural

363 landscape to achieve multiple benefits. Frontiers in Sustainable Food Systems. In revision.

364 Caravaca F, Figueroa D, Azcón-Aguilar C, Barea JM, Roldán A. 2003. Medium-term effects of

365 mycorrhizal inoculation and composted municipal waste addition on the establishment of

366 two Mediterranean shrub species under semiarid field conditions. Agriculture, Ecosystems

367 and Environment 97:95-105. DOI: 10.1016/S0167-8809(03)00126-9.

368 Castro AJ, Quintas-Soriano C, Egoh BN. 2018. Ecosystem services in dryland systems of the

369 world. Journal of Arid Environments 159:1-3. DOI: 10.1016/j.jaridenv.2018.09.006.

370 Chazdon RL, Brancalion PHS, Lamb D, Laestadius L, Calmon M, Kumar C. 2017. A Policy-

371 Driven Knowledge Agenda for Global Forest and Landscape Restoration. Conservation

$372 \quad$ Letters 10:125-132. DOI: 10.1111/conl.12220.

373 Clewell AF, Aronson J. 2006. Motivations for the restoration of ecosystems. Conservation

374 Biology 20:420-428. DOI: 10.1111/j.1523-1739.2006.00340.x.

375 Cote, I. M., Jennions MD. 2013. The procedure of meta-analysis in a nutshell. In: Handbook of

$376 \quad$ Meta-analysis in Ecology and Evolution. 14-26.

377 Crouzeilles R, Ferreira MS, Chazdon RL, Lindenmayer DB, Sansevero JBB, Monteiro L,

378 Iribarrem A, Latawiec AE, Strassburg BBN. 2017. Ecological restoration success is higher

379 for natural regeneration than for active restoration in tropical forests. Science Advances

$380 \quad 3: \mathrm{e} 1701345$.

381 DellaSala DA, Martin A, Spivak R, Schulke T, Bird B, Criley M, van Daalen C, Kreilick J,

382 Brown R, Aplet G. 2003. A Citizen's Call for Ecological Forest Restoration: Forest

383 Restoration Principles and Criteria. Ecological Restoration 21:14-23.

384 Diamond JM. 1975. Assembly of species communities. In: Cody, M. L. Diamond JM ed. 
Ecology and evolution of communities. Harvard University Press, Cambridge,

$386 \quad$ Massachusetts, USA., 342-444.

387 Díaz S, Pascual U, Stenseke M, Martín-López B, Watson RT, Molnár Z, Hill R, Chan KMA,

388 Baste IA, Brauman KA, Polasky S, Church A, Lonsdale M, Larigauderie A, Leadley PW,

389 van Oudenhoven APE, van der Plaat F, Schröter M, Lavorel S, Aumeeruddy-Thomas Y,

390 Bukvareva E, Davies K, Demissew S, Erpul G, Failler P, Guerra CA, Hewitt CL, Keune H,

391 Lindley S, Shirayama Y. 2018. Assessing nature’s contributions to people. Science

392 359:270-272. DOI: 10.1126/science.aap8826.

393 Durant SM, Pettorelli N, Bashir S, Woodroffe R, Wacher T, De Ornellas P, Ransom C, Abaigar

394 T, Abdelgadir M, El Alqamy H, Beddiaf M, Belbachir F, Belbachir-Bazi A, Berbash AA,

395 Beudels-Jamar R, Boitani L, Breitenmoser C, Cano M, Chardonnet P, Collen B, Cornforth

396 WA, Cuzin F, Gerngross P, Haddane B, Hadjeloum M, Jacobson A, Jebali A, Lamarque F,

397 Mallon D, Minkowski K, Monfort S, Ndoassal B, Newby J, Ngakoutou BE, Niagate B,

398 Purchase G, Samaila S, Samna AK, Sillero-Zubiri C, Soultan AE, Stanley Price MR, Baillie

399 JEM. 2012. Forgotten Biodiversity in Desert Ecosystems. Science 336:1379-1380. DOI:

$400 \quad 10.1126 /$ science.336.6087.1379.

401 ELD Initiative. 2015. Report for policy and decision makers: Reaping economic and 402 environmental benefits from sustainable land management.

403 Filazzola A, Brown C, Dettlaff MA, Batbaatar A, Grenke J, Bao T, Peetoom Heida I, Cahill JF.

404 2020. The effects of livestock grazing on biodiversity are multi-trophic: a meta-analysis.

$405 \quad$ Ecology Letters.

406 Garibaldi LA, Pérez-Méndez N, Garratt MPD, Gemmill-Herren B, Miguez FE, Dicks L V. 2019.

407 Policies for Ecological Intensification of Crop Production. Trends in Ecology and Evolution 
34:282-286. DOI: 10.1016/j.tree.2019.01.003.

409 Gavin S. 2010. Meta-analysis in applied ecology. Biology Letters 6:78-81. DOI:

$410 \quad 10.1098 / \mathrm{rsbl} .2009 .0546$.

411 Gotelli NJ, McCabe DJ. 2002. Species co-occurrence: A meta-analysis of J. M. Diamond's

412 assembly rules model. Ecology 83:2091-2096. DOI: 10.1890/0012-

$413 \quad$ 9658(2002)083[2091:SCOAMA]2.0.CO;2.

414 De Groot RS, Blignaut J, Van Der Ploeg S, Aronson J, Elmqvist T, Farley J. 2013. Benefits of

415 Investing in Ecosystem Restoration. Conservation Biology 27:1286-1293. DOI:

$416 \quad$ 10.1111/cobi.12158.

417 Gustafson EJ. 1998. Quantifying Landscape Spatial Pattern: What Is the State of the Art?

$418 \quad$ Ecosystems 1:143-156.

419 Hanak E, Escriva-Bou A, Gray B, Green S, Harter T, Jezdimirovic J, Lund J, Medellín-Azuara J, 420 Moyle P, Seavy N. 2019. Water and the Future of the San Joaquin Valley. DOI:

421 10.13140/RG.2.2.24360.83208.

422

423

424

425

426

427

428

429

430

Hayes GF, Holl KD. 2003. Cattle Grazing Impacts on Annual Forbs and Vegetation Composition of Mesic Grasslands in California. Conservation Biology 17:1694-1702. DOI: 10.1111/j.1523-1739.2003.00281.x.

Hedges, L. V, Gurevitch J, Curtis P. 1999. The Meta-Analysis of Response Ratios in Experimental Ecology. Ecology 80:1150-1156.

Hobbs RJ, Cramer VA. 2008. Restoration Ecology: Interventionist Approaches for Restoring and Maintaining Ecosystem Function in the Face of Rapid Environmental Change. Annual Review of Environment and Resources 33:39-61. DOI: 10.1146/annurev.energy.33.020107.113631. 
431 Holl KD, Aide TM. 2011. When and where to actively restore ecosystems? Forest Ecology and 432 Management 261:1558-1563.

433 Ioannidis JPA, Patsopoulos NA, Evangelou E. 2007. Uncertainty in heterogeneity estimates in 434 meta-analyses. British Medical Journal 335:914-916.

435 James JJ, Sheley RL, Erickson T, Rollins KS, Taylor MH, Dixon KW. 2013. A systems 436 approach to restoring degraded drylands. Journal of Applied Ecology 50:730-739. DOI: 10.1111/1365-2664.12090.

Kelsey R, Hart A, Scott Butterfield H, Vink D. 2018. Groundwater sustainability in the San Joaquin Valley: Multiple benefits if agricultural lands are retired and restored strategically. California Agriculture 72:151-154.

441 442

Kennedy CM, Oakleaf JR, Theobald DM, Baruch-Mordo S, Kiesecker J. 2019. Managing the middle: A shift in conservation priorities based on the global human modification gradient. Global Change Biology:811-826. DOI: 10.1111/gcb.14549.

Kleijn D, Bommarco R, Fijen TPM, Garibaldi LA, Potts SG, van der Putten WH. 2019. Ecological Intensification: Bridging the Gap between Science and Practice. Trends in Ecology and Evolution 34:154-166. DOI: 10.1016/j.tree.2018.11.002.

Koricheva J, Gurevitch J. 2014. Uses and misuses of meta-analysis in plant ecology. Journal of Ecology 102:828-844.

Koricheva J, Gurevitch J, Mengersen K. 2013. Handbook of Meta-Analysis In Ecology and Evolution. Princeton University Press.

Lajeunesse MJ. 2015. Bias and correction for the log response ratio in ecological meta-analysis. Ecology 96:2056-2063.

Lortie CJ, Filazzola A, Kelsey R, Hart AK, Butterfield HS. 2018. Better late than never: a 

synthesis of strategic land retirement and restoration in California. Ecosphere 9:e02367. DOI: $10.1002 /$ ecs2.2367.

456 457

Martonne E De. 1927. Regions of Interior-Basin Drainage. Geographical Review 17:397-414.

Marty JT. 2005. Effects of cattle grazing on diversity in ephemeral wetlands. Conservation Biology 19:1626-1632. DOI: 10.1111/j.1523-1739.2005.00198.x.

Meli P, Holl KD, Benayas JMR, Jones HP, Jones PC, Montoya D, Mateos DM. 2017. A global review of past land use, climate, and active vs. passive restoration effects on forest recovery. PLoS ONE 12:1-17.

Miguel FM, Butterfield SH, Lortie C. 2020. A synthesis dataset describing dryland agricultural restoration practices. figshare. Dataset.

Millennium Ecosystems Assessment (MEA). 2005. Dryland Systems. In: Ecosystems and Human well-being: Current State and Trends. 1-40. DOI: 10.1196/annals.1439.003.

Miller RJ, Hobbs JR. 2007. Habitat restoration - do we know what we're doing? Restoration Ecology 15:382-390.

Moher D, Liberati A, Tetzlaff J, Altman DG, Altman D, Antes G, Atkins D, Barbour V, Barrowman N, Berlin JA, Clark J, Clarke M, Cook D, D’Amico R, Deeks JJ, Devereaux PJ, Dickersin K, Egger M, Ernst E, Gøtzsche PC, Grimshaw J, Guyatt G, Higgins J, Ioannidis JPA, Kleijnen J, Lang T, Magrini N, McNamee D, Moja L, Mulrow C, Napoli M, Oxman A, Pham B, Rennie D, Sampson M, Schulz KF, Shekelle PG, Tovey D, Tugwell P. 2009. Preferred reporting items for systematic reviews and meta-analyses: The PRISMA statement. PLoS Medicine 7:889-896. DOI: 10.3736/jcim20090918.

Perino A, Pereira HM, Navarro LM, Fernández N, Bullock JM, Ceaușu S, Cortés-Avizanda A, van Klink R, Kuemmerle T, Lomba A, Pe'er G, Plieninger T, Rey Benayas JM, Sandom CJ, 
Svenning J-C, Wheeler HC. 2019. Rewilding complex ecosystems. Science 364:eaav5570. DOI: $10.1126 /$ science.aav5570.

479 Pustejovsky JE. 2018. Using response ratios for meta-analyzing single-case designs with $480 \quad$ behavioral outcomes. Journal of School Psychology 68:99-112.

481 Queiroz C, Beilin R, Folke C, Lindborg R. 2014. Farmland abandonment: Threat or opportunity 482 for biodiversity conservation? A global review. Frontiers in Ecology and the Environment 483 12:288-296. DOI: 10.1890/120348.

R Core Team. 2018. R: A language and environment for statistical computing. $R$ Foundation for 485 Statistical Computing, Vienna, Austria. URL https://www.R-project.org/.

Ramankutty N, Evan AT, Monfreda C, Foley JA. 2008. Farming the planet: 1. Geographic distribution of global agricultural lands in the year 2000. Global Biogeochemical Cycles 22:1-19. DOI: 10.1029/2007GB002952.

Reid W V, Mooney HA, Cropper A, Capistrano D, Carpenter SR, Chopra K, Dasgupta P, Dietz T. 2005. Ecosystems and Human Well-being: Synthesis. DOI: 10.1196/annals.1439.003.

Reynolds JF, Smith DMS, Lambin EF, Turner BL, Mortimore M, Batterbury SPJ, Downing TE, Dowlatabadi H, Fernandez RJ, Herrick JE, Huber-Sannwald E, Jiang H, Leemans R, Lynam T, Maestre FT, Ayarza M, Walker B. 2007. Global Desertification: Building a Science for

Schwarzer G. 2007. meta: An R package for meta-analysis. $R$ news 7:40-45.

497 Schwarzer G, Carpenter JR, Rücker G. 2015. Meta-Analysis with R. New York: Springer.

498 Tilman D, Balzer C, Hill J, Befort BL. 2011. Global food demand and the sustainable 499 intensification of agriculture. Proceedings of the National Academy of Sciences of the 
United States of America 108:20260-20264. DOI: 10.1073/pnas.1116437108.

501 Török K, Szitár K, Halassy M, Szabó R, Szili-Kovács T, Baráth N, Paschke MW. 2014. Long-

502 term outcome of nitrogen immobilization to restore endemic sand grassland in Hungary.

503 Journal of Applied Ecology 51:756-765. DOI: 10.1111/1365-2664.12220.

504 Viechtbauer W. 2010. Conducting meta-analyses in R with the metafor package. Journal of $505 \quad$ Statistical Software 36:1-48.

506 Webb NP, Marshall NA, Stringer LC, Reed MS, Chappell A, Herrick JE. 2017. Land

507 degradation and climate change : building climate resilience in agriculture. Frontiers in 508 Ecology and the Environment 15:450-459. DOI: 10.1002/fee.1530.

509 White RP, Nackoney J. 2003. Drylands, people, and ecosystem goods and services: A Web-

510 Based Geospatial Analysis. In: World Resources Institute, Washington, D.C., USA.

511 World Health Organization. 2018. The state of food security and nutrition in the world 2018:

$512 \quad$ building climate resilience for food security and nutrition.

513 Wortley L, Hero JM, Howes M. 2013. Evaluating ecological restoration success: A review of the $514 \quad$ literature. Restoration Ecology 21:537-543. 


\section{Table $\mathbf{1}$ (on next page)}

Table 1. List of crop and animal grazer species in farmlands and grazing lands prior to the implementation of active and passive restoration practices in dryland agricultural ecosystems globally.

Each restoration practice was categorized as active or passive. Different practices were grouped into general categories based on their primary focus, for example those related with plant interventions such as planting or seeding, were included within the vegetation category. 
1 Table 1. List of crop and animal grazer species in farmlands and grazing lands prior to the

2 implementation of active and passive restoration practices in dryland agricultural ecosystems

3 globally.

4 Each restoration practice was categorized as active or passive. Different practices were grouped

5 into general categories based on their primary focus, for example those related with plant

6 interventions such as planting or seeding, were included within the vegetation category.

7

\begin{tabular}{|c|c|c|c|c|}
\hline Farmlands & Grazing lands & Restoration & $\begin{array}{c}\text { Category of } \\
\text { practices }\end{array}$ & Practices \\
\hline \multirow{2}{*}{$\begin{array}{l}\text { Avena chinensis } \\
\text { Brassica nigra } \\
\text { Erigeron canadensis } \\
\text { Fagopyrum sagittatum } \\
\text { Kochia scoparia } \\
\text { Lactuca scariola } \\
\text { Linum usitatissimum } \\
\text { Medicago sativa } \\
\text { Pisum sativum } \\
\text { Salsola iberica } \\
\text { Schismus spp } \\
\text { Sesamum indicum } \\
\text { Solanum tuberosum } \\
\text { Triticum aestivum } \\
\text { cotton } \\
\text { corn } \\
\text { mellon } \\
\text { pecans } \\
\text { watermelon }\end{array}$} & \multirow[t]{3}{*}{$\begin{array}{l}\text { cattle } \\
\text { livestock }\end{array}$} & \multirow[t]{3}{*}{ Active } & vegetation & $\begin{array}{l}\text { seeding } \\
\text { seeding, mowing and } \\
\text { herbicide, mulching } \\
\text { seeding, mulching, weeding } \\
\text { seeding, irrigation } \\
\text { seeding and ripping } \\
\text { mechanical disturbance and } \\
\text { seeding } \\
\text { seeding, safe sites for seeds } \\
\text { and fencing } \\
\text { planting }\end{array}$ \\
\hline & & & water supplementation & $\begin{array}{l}\text { water supplementation } \\
\text { seeding and irrigation }\end{array}$ \\
\hline not listed in studies & & & soil & $\begin{array}{l}\text { carbon addition } \\
\text { mycorrhizal inoculation }\end{array}$ \\
\hline $\begin{array}{l}\text { Medicago spp } \\
\text { Melilotus albus } \\
\text { Mentha spp } \\
\text { Triticum aestivum } \\
\text { Zea mays } \\
\text { fruits-vegetables } \\
\text { forage crops }\end{array}$ & $\begin{array}{l}\text { sheep and goat } \\
\text { cattle } \\
\text { livestock }\end{array}$ & \multirow{3}{*}{ Passive } & vegetation & $\begin{array}{l}\text { natural recovery } \\
\text { grazing exclusion } \\
\text { facilitation }\end{array}$ \\
\hline- & $\begin{array}{l}\text { livestock } \\
\text { cattle } \\
\text { sheep } \\
\text { livestock }\end{array}$ & & grazing exclusion & $\begin{array}{l}\text { grazing exclusion } \\
\text { facilitation } \\
\text { natural recovery }\end{array}$ \\
\hline $\begin{array}{l}\text { Solanum tuberosum } \\
\text { cereal crops-fallow } \\
\text { chinese onion } \\
\text { peanut } \\
\text { sorghum } \\
\end{array}$ & - & & soil & $\begin{array}{l}\text { natural recovery } \\
\text { mycorrhizal recovery }\end{array}$ \\
\hline
\end{tabular}

8 


\section{Table 2 (on next page)}

Table 2. Distribution of studies evaluating restoration practices in dryland agricultural ecosystems.

List of countries $(n=16)$ included in the meta-analysis, their active or passive restoration focus and the restoration practice implemented. Different restoration practices were grouped into general categories based on their primary focus, for example those related with plant interventions such as planting or seeding, were included within the vegetation category. 
1 Table 2. Distribution of studies evaluating restoration practices in dryland agricultural

2 ecosystems ( $\mathrm{n}=42$ and 1,427 data entries).

3 List of countries $(\mathrm{n}=16)$ included in the meta-analysis, their active or passive restoration focus

4 and the restoration practice implemented. Different restoration practices were grouped into

5 general categories based on their primary focus, for example those related with plant

6 interventions such as planting or seeding, were included within the vegetation category.

\begin{tabular}{|l|l|l|c|}
\hline Country & Restoration & \multicolumn{1}{l}{ Category of practices } & Data entries \\
\hline \multirow{2}{*}{ Argentina } & Active & vegetation & 13 \\
& Passive & vegetation & 10 \\
\hline Australia & Active & vegetation & 12 \\
\hline Canada & Active & vegetation & 30 \\
\hline & Active & vegetation & 622 \\
& & water supplementation & 12 \\
China & Passive & grazing exclusion & 30 \\
& & soil & 204 \\
& Passive & vegetation & 42 \\
\hline Egypt & Passive & grazing exclusion & 21 \\
\hline Ethiopia & Active & soil & 5 \\
\hline Hungary & Passive & vegetation & 27 \\
\hline Iran & Active & vegetation & 15 \\
\hline Kenya & Passive & vegetation & 7 \\
\hline Kuwait & Active & vegetation & 10 \\
\hline \multirow{2}{*}{ Mongolia } & Passive & vegetation & 24 \\
\hline Portugal & Passive & grazing exclusion & 37 \\
\hline Russia & Passive & soil & 21 \\
\hline South Africa & Active & vegetation & 4 \\
\hline Spain & Active & soil & 93 \\
\hline United States of & Active & vegetation & 28 \\
\hline America & Passive & water supplementation & 63 \\
\hline
\end{tabular}




\section{Table 3 (on next page)}

Table 3. List of restoration practices, desired restoration goals (i.e. outcomes) and original response variables included in the meta-analysis.

Data was used to compare active versus passive restoration practices in dryland agricultural ecosystems globally ( $n=42$ and 1,427 independent observations or data entries). Different practices were grouped into general categories based on their primary focus, for example those related with plant interventions such as planting or seeding, were included within the vegetation category. The outcomes listed describe restoration goals from each restoration practice; the habitat classification includes studies that reported measures of both soil and vegetation recovery or of vegetation community structure. 
1 Table 3. List of restoration practices, desired restoration goals (i.e. outcomes) and original

2 response variables included in the meta-analysis.

3 Data was used to compare active versus passive restoration practices in dryland agricultural

4 ecosystems globally ( $\mathrm{n}=42$ and 1,427 independent observations or data entries). Different

5 practices were grouped into general categories based on their primary focus, for example those

6 related with plant interventions such as planting or seeding, were included within the vegetation

7 category. The outcomes listed describe restoration goals from each restoration practice; the

8 habitat classification includes studies that reported measures of both soil and vegetation recovery

9 or of vegetation community structure.

10

\begin{tabular}{|c|c|c|c|c|c|}
\hline Restoration & $\begin{array}{l}\text { Category of } \\
\text { Practices }\end{array}$ & Practices & Outcomes & Response variables & $\begin{array}{c}\text { Data } \\
\text { entries }\end{array}$ \\
\hline \multirow{20}{*}{ Active } & \multirow[b]{2}{*}{ soil } & carbon amendment & soil & moss cover; soil nutrient content & 27 \\
\hline & & $\begin{array}{l}\text { mycorrhizal } \\
\text { inoculation }\end{array}$ & vegetation & plant biomass; nutrient & 128 \\
\hline & \multirow{16}{*}{ vegetation } & burning, mowing & habitat & soil nutrient content and soil properties & 24 \\
\hline & & $\begin{array}{l}\text { mechanical } \\
\text { disturbance, seeding }\end{array}$ & vegetation & plant cover and density & 4 \\
\hline & & planting & habitat & $\begin{array}{l}\text { plant biomass, density, cover, diversity and } \\
\text { richness; soil nutrient }\end{array}$ & 369 \\
\hline & & planting & vegetation & $\begin{array}{l}\text { plant height and cover; invertebrate and lizard } \\
\text { abundance, diversity, dominance, evenness and } \\
\text { richness }\end{array}$ & 26 \\
\hline & & planting & soil & soil nutrient content and soil properties & 84 \\
\hline & & planting & animals & invertebrate abundance, diversity and richness & 6 \\
\hline & & $\begin{array}{l}\text { planting, grazing } \\
\text { exclusion }\end{array}$ & animals & $\begin{array}{l}\text { arthropod abundance, richness and diversity; soil } \\
\text { properties; plant cover, density, height and } \\
\text { richness }\end{array}$ & 24 \\
\hline & & seeding & vegetation & $\begin{array}{l}\text { plant cover and density; seedling emergence and } \\
\text { establishment }\end{array}$ & 53 \\
\hline & & seeding & soil & soil nutrient content and soil properties & 117 \\
\hline & & seeding and ripping & vegetation & plant cover and abundance & 12 \\
\hline & & $\begin{array}{l}\text { seeding, gypsum and } \\
\text { organic mulch }\end{array}$ & habitat & $\begin{array}{l}\text { soil properties; seedling emergence and surviving } \\
\text { plants }\end{array}$ & 9 \\
\hline & & seeding, irrigation & vegetation & seedling emergence & 7 \\
\hline & & $\begin{array}{l}\text { seeding, mowing and } \\
\text { herbicide, mulching }\end{array}$ & habitat & $\begin{array}{l}\text { plant cover and richness; soil nutrient content and } \\
\text { soil properties }\end{array}$ & 18 \\
\hline & & $\begin{array}{l}\text { seeding, mulching, } \\
\text { weeding }\end{array}$ & vegetation & plant cover & 6 \\
\hline & & $\begin{array}{l}\text { seeding, safe sites for } \\
\text { seeds, fencing }\end{array}$ & vegetation & plant cover and biomass & 8 \\
\hline & & $\begin{array}{l}\text { seeding, soil tilling, } \\
\text { fertilization }\end{array}$ & vegetation & plant biomass & 7 \\
\hline & \multirow{2}{*}{$\begin{array}{l}\text { water } \\
\text { supplementation }\end{array}$} & irrigation, seeding & vegetation & $\begin{array}{l}\text { plant cover, abundance, biomass, density and } \\
\text { survival }\end{array}$ & 63 \\
\hline & & water supply & habitat & $\begin{array}{l}\text { plant biomass, density, cover, evenness, } \\
\text { productivity and richness; soil nutrient content }\end{array}$ & 12 \\
\hline \multirow{2}{*}{ Passive } & \multirow{2}{*}{ grazing exclusion } & fencing & vegetation & plant height, cover and diversity & 21 \\
\hline & & grazing exclusion & vegetation & plant height, cover, diversity, biomass and & 8 \\
\hline
\end{tabular}




\begin{tabular}{|c|c|c|c|c|}
\hline & & & richness & \\
\hline & natural recovery & vegetation & plant biomass, cover, density, height & 27 \\
\hline \multirow{2}{*}{ soil } & mycorrhizal recovery & soil & microbial richness and density & 6 \\
\hline & natural recovery & soil & soil nutrient content and soil properties & 202 \\
\hline \multirow{6}{*}{ vegetation } & facilitation & habitat & $\begin{array}{l}\text { soil nutrient content and soil properties; plant } \\
\text { survival, biomass, height, width, abundance, and } \\
\text { richness }\end{array}$ & 60 \\
\hline & natural recovery & habitat & $\begin{array}{l}\text { soil nutrient content and soil properties; plant } \\
\text { richness }\end{array}$ & 40 \\
\hline & natural recovery & animals & arthropod density, diversity and richness & 3 \\
\hline & natural recovery & soil & soil properties & 18 \\
\hline & fencing & habitat & $\begin{array}{l}\text { plant biomass, evenness, cover, density, diversity, } \\
\text { height and richness; soil nutrient content and soil } \\
\text { properties }\end{array}$ & 15 \\
\hline & grazing exclusion & vegetation & plant cover, density, height, biomass and richness & 23 \\
\hline
\end{tabular}

11

12

13

14

15 


\section{Table 4 (on next page)}

Table 4. The effect of active and passive restoration practices and restoration outcomes evaluated in dryland agricultural - here, defined as farmlands and grazing lands ecosystems globally.

The log response ratio (effect size) and 95\% confidence interval (Cl) were calculated from random effects models (Lortie, C.J. and Miguel, M.F. 2019. R code, DOI:

10.5281/zenodo.3907012). Effect of active and passive restoration practices was tested by ttest against a value of 0 , and restoration practices and outcomes were considered significant if their estimated $95 \%$ confidence intervals did not overlap 0. (A) Random effects model results comparing restoration practices. (B) Random effects model results comparing restoration outcomes. Outcomes describe target goals from each restoration practice; the habitat category includes studies that reported measures of both soil and vegetation restoration or general community structure. 
1 Table 4. The effect of active and passive restoration practices and restoration outcomes

2 evaluated in dryland agricultural - here, defined as farmlands and grazing lands - ecosystems

3 globally.

4 The log response ratio (effect size) and $95 \%$ confidence interval (CI) were calculated from

5 random effects models (Lortie, C.J. and Miguel, M.F. 2019. R code, DOI:

6 10.5281/zenodo.3907012). Effect of active and passive restoration practices was tested by t-test

7 against a value of 0 , and restoration practices and outcomes were considered significant if their

8 estimated 95\% confidence intervals did not overlap 0. (A) Random effects model results

9 comparing restoration practices. (B) Random effects model results comparing restoration

10 outcomes. Outcomes describe target goals from each restoration practice; the habitat category

11 includes studies that reported measures of both soil and vegetation restoration or general

12 community structure.

\begin{tabular}{|lcc|}
\hline Restoration & Log Response Ratio & $\mathbf{9 5 \%}$ CI \\
(A) & & \\
Active practices & 0.34 & $0.27,0.42$ \\
Water supplementation & 0.64 & $0.55,0.73$ \\
Soil & 0.56 & $0.54,0.57$ \\
Vegetation & 0.19 & $0.18,0.21$ \\
Passive practices & -0.29 & $-0.36,-0.21$ \\
Soil & -0.74 & $-0.81,-0.68$ \\
Vegetation & 0.23 & $0.18,0.28$ \\
Grazing exclusion & 0.13 & $0.06,0.20$ \\
(B) & & \\
Active restoration outcomes & &
\end{tabular}




\begin{tabular}{lll|} 
Vegetation & 0.50 & $0.49,0.52$ \\
Soil & 0.28 & $0.21,0.35$ \\
Habitat & 0.10 & $0.09,0.12$ \\
Animals & -0.11 & $-0.113,-0.112$ \\
Passive restoration outcomes & & \\
Soil & -0.68 & $-0.74,-0.62$ \\
Vegetation & 0.29 & $0.23,0.35$ \\
Habitat & 0.13 & $0.07,0.19$ \\
Animals & 1.05 & $-0.21,2.31$ \\
\hline
\end{tabular}

14

15 
Figure 1

Figure 1. PRISMA (Preferred Reporting Items for Systematic Reviews and Meta-Analyses) flowchart. PRISMA report of a meta-analysis comparing active versus passive restoration practices in dryland agricultural ecosystems globally. 


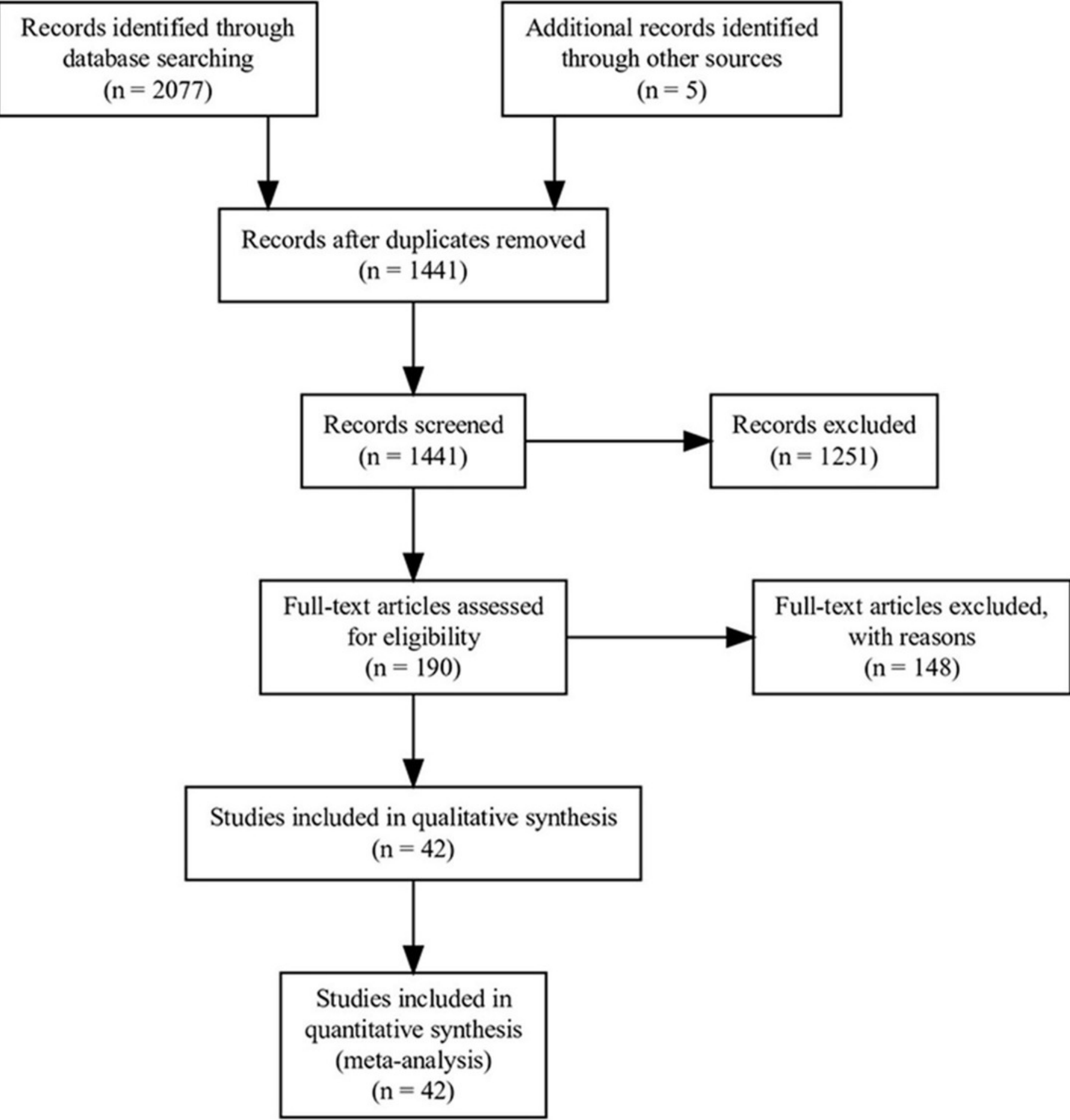




\section{Figure 2}

Figure 2. Frequency of terminologies referring to agricultural land uses in dryland ecosystems.

Different terms were applied in studies included in the meta-analysis comparing active and passive restoration practices in agricultural dryland ecosystems globally. These terminologies were grouped into a single term - "agricultural dryland ecosystems", including farmlands (cultivation, farmland, agricultural land, cropland, agriculture, and agricultural field) and grazing lands (grazing and overgrazing terms).

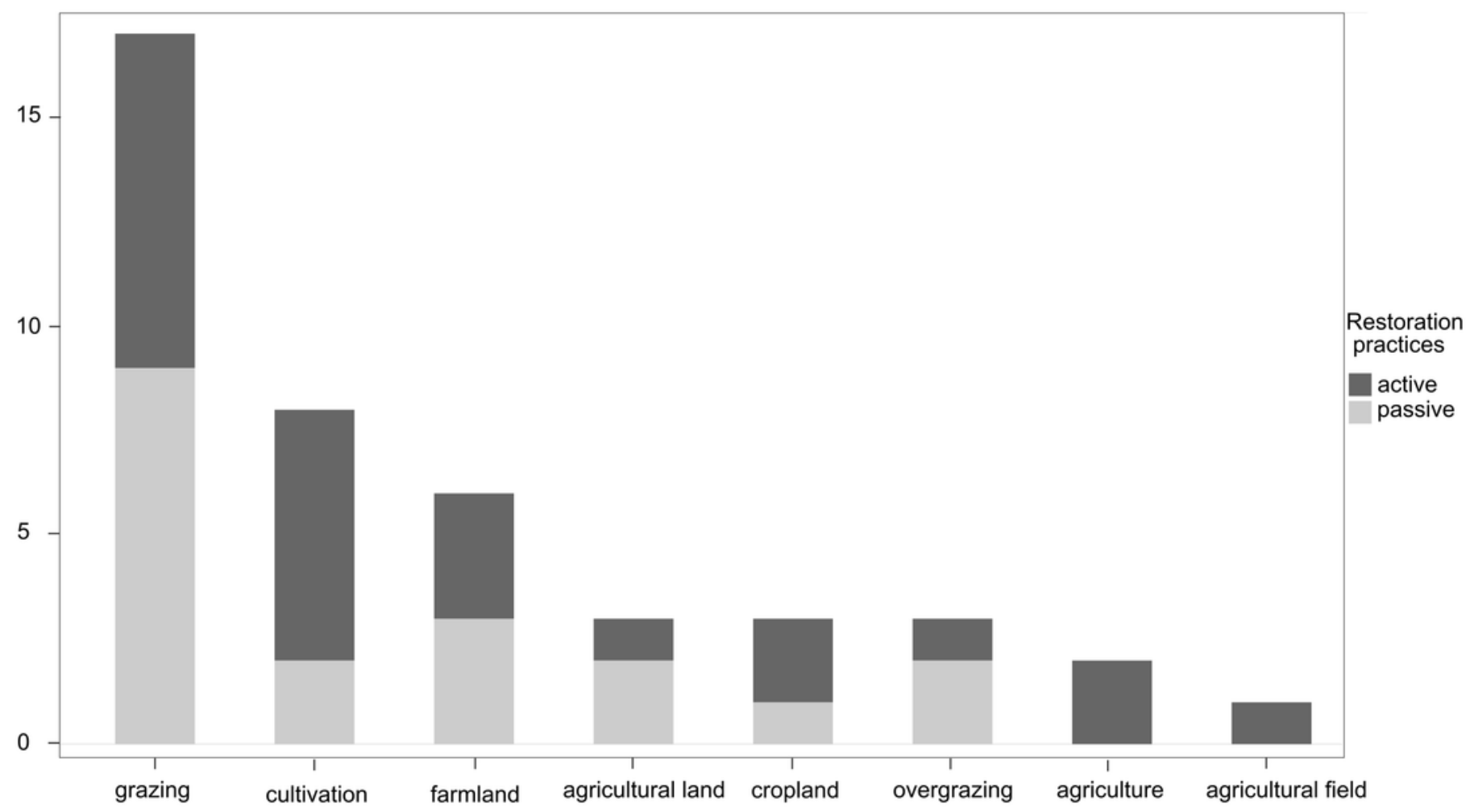


Figure 3

Figure 3. Global distribution of studies evaluating restoration practices in dryland agricultural ecosystems $(n=42)$.

Restoration practices included in the meta-analysis were classified into active or passive.

Dark gray points represent the location of studies that used active restoration practices.

Lighter gray points represent the location of studies that used passive restoration practices.

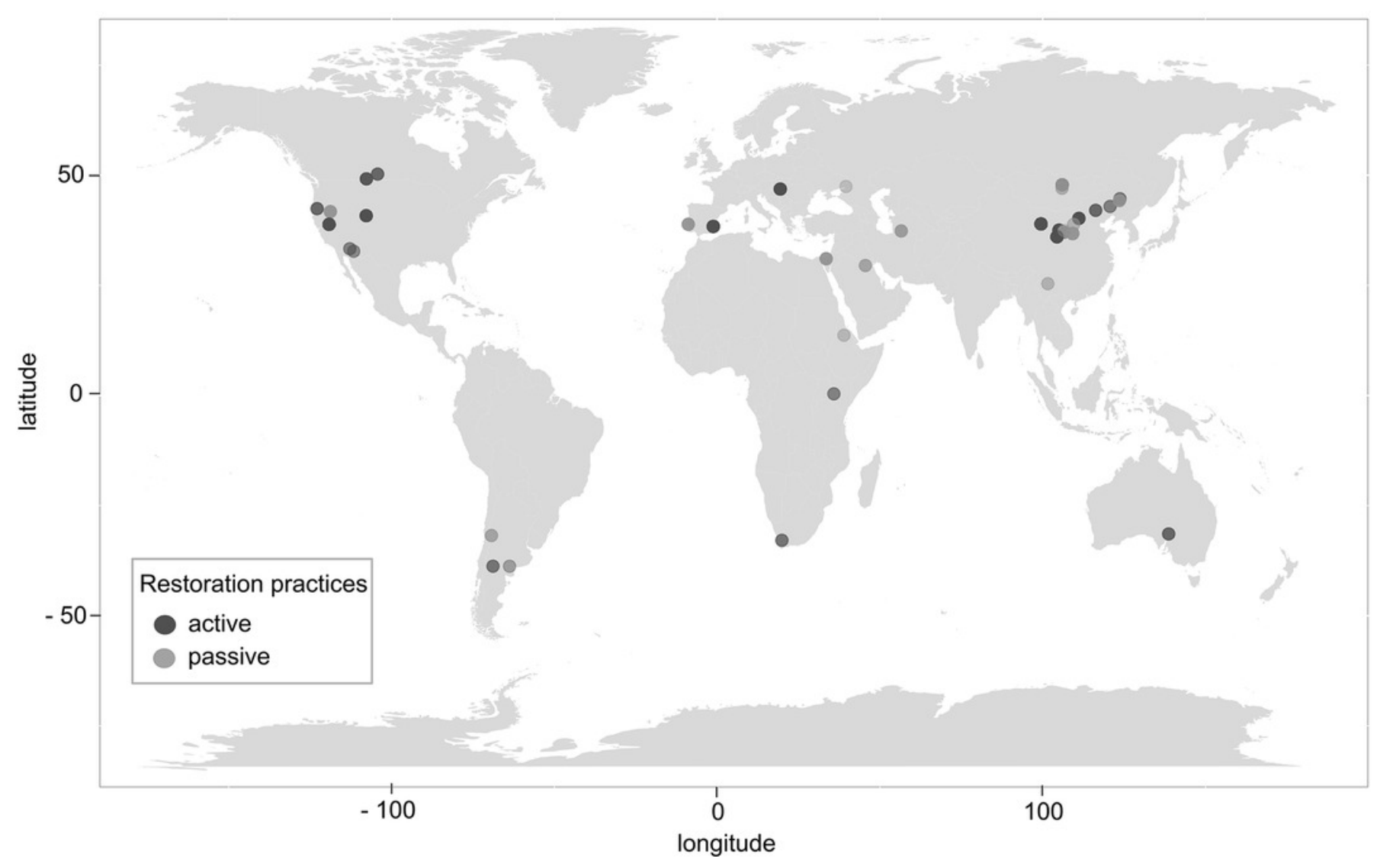




\section{Figure 4}

Figure 4. Log response ratio (effect size) and 95\% confidence intervals for active and passive restoration practices in agricultural dryland ecosystems.

The dashed vertical line denotes no effect of restoration practices, or a mean of zero. A positive log response ratio value indicates the mean of the restoration practice was higher than that of the reference condition and a negative value indicates the mean of the reference condition was higher than that of the restoration practice. The $p$-values are from random effect models comparing subgroups differences among restoration practices.

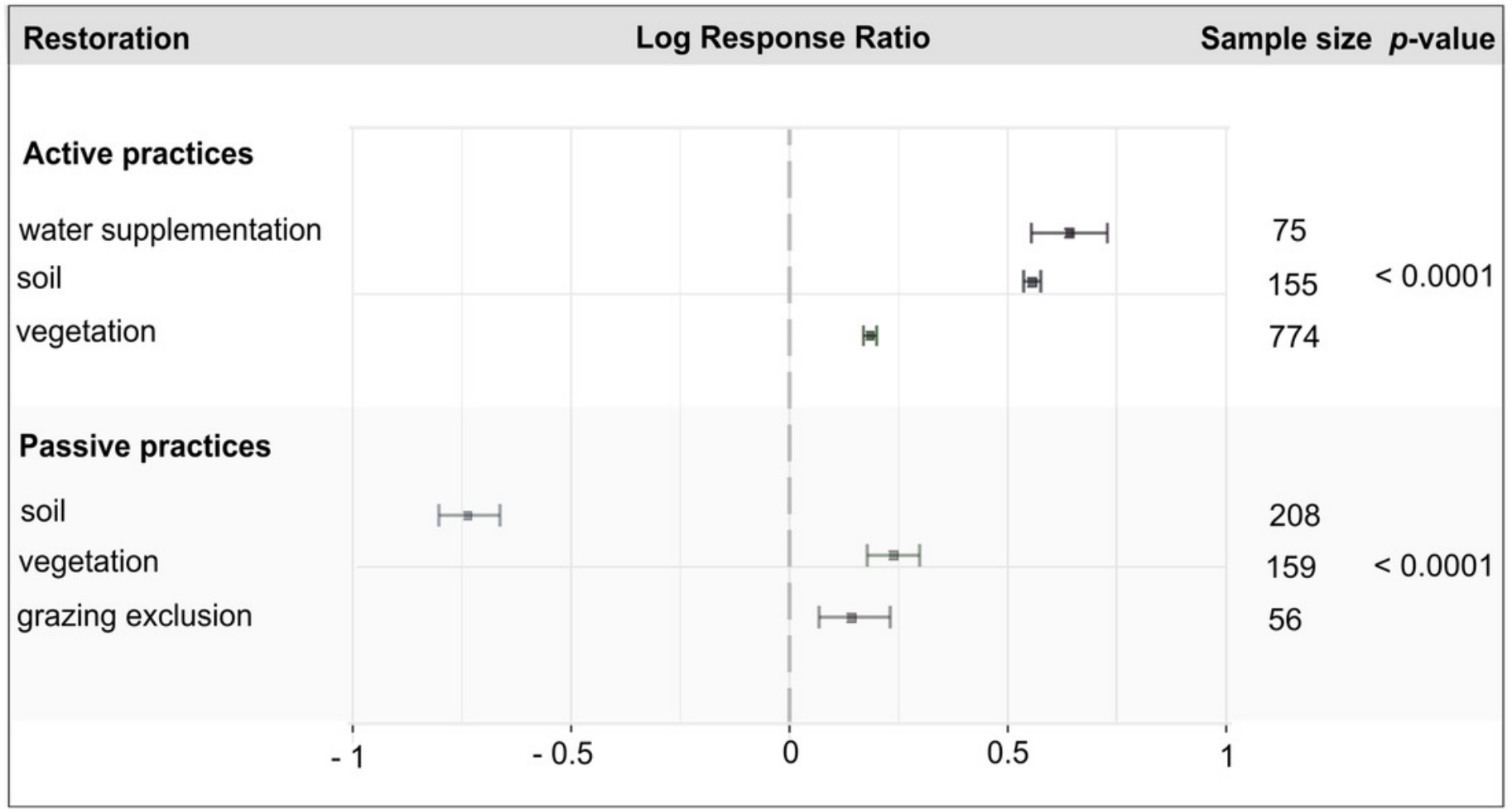

